\title{
Effect of ascorbic acid on the serum folic acid estimation
}

\author{
I. J. TEMPERLEY AND NUALA HORNER
}

From the School of Pathology, Trinity College, Dublin

SYNOPSIS Ascorbic acid added to the basal medium increased the growth response of Lactobacillus casei in folic acid standards. The effect in the serum extracts was not marked, resulting in lowered serum folic acid estimations. However, results obtained on prolonged incubation were similar whether ascorbic acid was added or not. The presence or absence of ascorbic acid and variation of the incubation period may account for differences in reported normal ranges of serum folic acid levels.

The ability of ascorbic acid to preserve folic acid in serum extracts during heating has been demonstrated by Toennies, Usdin, and Phillips (1956). This observation has been utilized by other workers who have published methods for estimating serum folic acid (Baker, Herbert, Frank, Pasher, Hutner, Wasserman, and Sobotka, 1959; Waters and Mollin, 1961). The estimation of folic acid is dependent upon comparing the growth of a test organism in serum extracts with growth in a series of standard folic acid concentrations. Some reported methods indicate the addition of ascorbic acid to serum extracts but not to the standards. This report presents evidence that the addition of ascorbic acid to the basal medium affects the results of serum folic acid estimations using Lactobacillus casei as the test organism.

\section{METHODS}

Solid medium (Difco Laboratories folic acid casei medium) was rehydrated by suspending $4.7 \mathrm{~g}$. in $100 \mathrm{ml}$. water. This concentration was found satisfactory for the assay in this laboratory. The medium does not contain ascorbic acid. For routine purposes the $p \mathrm{H}$ of the medium was lowered to 6.1 with $\mathrm{N} / 10 \mathrm{H}_{2} \mathrm{SO}_{4}$ and finally $100 \mathrm{mg} . \%$ ascorbic acid was added. Serum $(2.0 \mathrm{ml}$.) was added to $10 \mathrm{mg}$. dry ascorbic acid and stored at $-20^{\circ} \mathrm{C}$. A $200 \mathrm{mg} . \%$ solution of ascorbic acid in $0 \cdot 1 \mathrm{M}$ phosphate buffer at $p H 6.1$ prepared. Serum was mixed with the buffered ascorbic acid solution in the proportion of 1 to 9. Protein was precipitated by autoclaving for two and a half minutes at $15 \mathrm{lb}$. pressure. The clear supernatant obtained by cooling and centrifuging was diluted 1 in 4 with water (1/40 dilution). Two millilitres of medium

Received for publication 25 May 1965. were added to test tubes by automatic pipetting. Tubes containing from 0.0 to $0.5 \mathrm{ng}$. folic acid were set up in quadruplicate and water was added to make a final volume of $4.0 \mathrm{ml}$. Two millilitres of the 1 in 40 serum dilutions were added to each of three tubes (1/20 dilution) and $1.0 \mathrm{ml}$. to each of three further tubes (1/40 dilution). The latter tubes were made up to $4.0 \mathrm{ml}$. with ascorbic acid buffer solution treated in a similar fashion as the serum extract. All tubes were autoclaved at $10 \mathrm{lb}$. for 10 minutes. Stock cultures of Lactobacillus casei (NCIB 6375) were carried in milk tryptose medium (Spray, 1955). A dilute suspension of the test organism in sterile water was obtained from a 24-hour growth in Bacto lactobacilli broth. The assay tubes were inoculated from the dilute suspension. Density of growth was routinely read after 44 hours' incubation at $37^{\circ} \mathrm{C}$.

\section{RESULTS}

The addition of ascorbic acid to the basal medium had an effect on growth in standards, in serum extracts, and on serum folic acid estimation.

EFFECT ON GROWTH IN STANDARDS The growth of $L$. case i in standard tubes with and without the added $100 \mathrm{mg} . \%$ ascorbic acid to the medium was compared after 20 and 48 hours' incubation in the same assay batch. Figure 1 shows that ascorbic acid increased the rate of growth and eliminated a sigmoid pattern in the growth curve at low concentrations of folic acid. The result of adding 50, 75, and $100 \mathrm{mg} . \%$ ascorbic acid to the medium was compared; optical densities and serum folic acid levels read from standard curves were similar.

EFFECT ON GROWTH IN SERUM EXTRACT The mean 


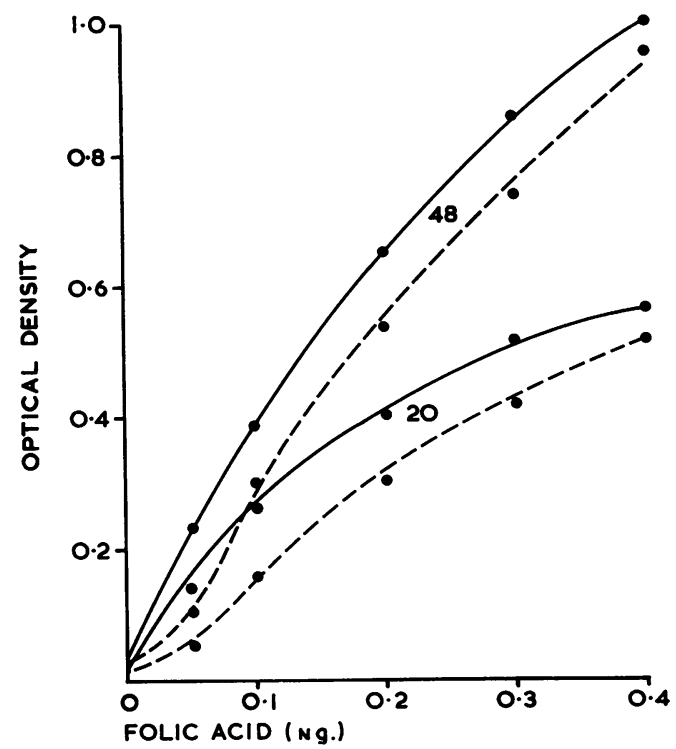

FIG. 1. The growth response of $\mathrm{L}$. casei to folic acid at 20 and 48 hours' incubation. The continuous line represents growth in the presence of, and the interrupted line growth in the absence of, ascorbic acid.

optical density of 24 observations (1/20 and $1 / 40$ dilutions) from 12 sera in medium containing $100 \mathrm{mg} . \%$ ascorbic acid was 0.24 and in medium with no added ascorbic acid 0.23 at 20 hours' incubation. The mean optical density at 48 hours' incubation with added ascorbic acid was 0.41 and without it was 0.38. All readings from each serum were from the same assay batch.

EFFECT ON RESULTS OF THE SERUM FOLIC ACID ESTIMATION Because of the above findings results of the serum folic acid tended to be higher in the absence of added ascorbic acid (Table I). The 12 sera in this table were estimated in three assay batches; all results of the same serum were from the one assay batch. The rate of growth in the standards and serum extracts was constant in the presence of added ascorbic acid after 20 hours' incubation. In the absence of added ascorbic acid the rate of growth increased in the standards compared with the serum extracts as incubation progressed so that ultimately results from both systems approximated (Table II).

Using our routine method with added ascorbic acid to the medium at $p \mathrm{H} 6 \cdot 1$, recovery of $4.0 \mathrm{ng}$. folic acid to 12 sera varied from 80 to $110 \%$ with a mean of $97 \%$. The addition of $100 \mathrm{mg} . \%$ ascorbic acid lowers the $p \mathrm{H}$ from an initial $7 \cdot 1$ to 6.5 and from 6.1 (see methods) to 5.9. However, lowering
TABLE I

RESULTS OBTAINED AFTER 20 AND 48 HOURS WITH AND WITHOUT 100 MG. $\%$ ASCORBIC ACID ADDED TO THE BAS 9 Q MEDIUM



TABLE II

EFFECT OF PROLONGED INCUBATION ON RESULTS Incubation Period (hr.)



RESULTS IN NORMAL SUBJECTS AND VARIOUS DISEASE GROU용

\begin{tabular}{|c|c|c|c|}
\hline & Number & $\begin{array}{l}\text { Mean } \\
\text { (ng./ml.) }\end{array}$ & $\begin{array}{l}\text { Range } \\
(\text { ng./ml. })\end{array}$ \\
\hline Control subjects & 40 & $5 \cdot 1$ & $2.1-9.5$ \\
\hline Coeliac disease & 28 & $2 \cdot 1$ & $0.3-5 \cdot 1=$ \\
\hline Idiopathic steatorrhoea & 6 & $1 \cdot 1$ & $0.5-2.4$ \\
\hline $\begin{array}{l}\text { Megaloblastic anaemia } \\
\text { responsive to folic acid } \\
\text { only }\end{array}$ & 10 & 0.7 & $0 \cdot 3-1 \cdot 2$ \\
\hline
\end{tabular}

the $p \mathrm{H}$ with $\mathrm{N} / 10 \mathrm{H}_{2} \mathrm{SO}_{4}$ did not mimic the effect of ascorbic acid.

RESULTS IN NORMAL SUBJECTS, PATIENTS WIL్ MALABSORPTION SYNDROME, AND MEGALOBLASTIC ANAEMIA RESPONSIVE TO FOLIC ACID Results in 9 normal subjects ranged from $2 \cdot 1$ to $9.5 \mathrm{ng} . / \mathrm{ml}$. with a mean of $5 \cdot 1 \mathrm{ng} . / \mathrm{ml}$. (Table III). This group wăs composed of 19 medical staff or students and blood donors. Folic acid levels in patients wi megaloblastic anaemia responsive only to folic aofid ranged from 0.3 to $1.2 \mathrm{ng} . / \mathrm{ml}$. with a mean of 0.4 ng./ml; seven patients had either idiopathic steate- 
rhoea or coeliac disease and two had megaloblastic anaemia of pregnancy. All patients included under idiopathic steatorrhoea in Table III were untreated; some of the patients included under coeliac disease had received intermittently a gluten-free diet.

\section{DISCUSSION}

The addition of ascorbic acid during the preparation of the serum extract provides an extra factor which which must be accounted for when the method of serum folic acid estimation, using $L$. case $i$ as the test organism, is being assessed. Waters and Mollin (1961) found that ascorbic acid has little or no effect on growth response in the standard tubes. Herbert (1961), however, maintained that ascorbic acid increases growth in the standards and that if ascorbic acid is not added to the standards erroneously high results are obtained. Spray (1964) found an increased growth response in the standards by adding $125 \mathrm{mg} . \%$ ascorbic acid to the medium. In the present study the addition of $100 \mathrm{mg} . \%$ ascorbic acid to the medium increased growth response in the standards but had less effect on the serum extracts. The latter finding is due to the presence of ascorbic acid already in the serum extracts. The result, therefore, was that serum folic acid levels were lower when ascorbic acid was added to the medium. The difference between results depended upon the length of incubation. Without added ascorbic acid results gradually fell as incubation progressed until serum folic acid levels read from two systems were similar. This suggests that ascorbic acid is not an essential factor for metabolism of folic acid by $L$. casei.

This study was undertaken to explain what ap- peared to be low serum folic acid levels in normal subjects when compared with a lower limit of normal of $7.5 \mathrm{ng} . / \mathrm{ml}$. (Herbert, Baker, Frank, Pasher, Sobokta, and Wasserman, 1960) and $5.9 \mathrm{ng} . / \mathrm{ml}$. (Waters and Mollin, 1961). Since initiation of our investigation Spray (1964) has reported a lower limit of normal of $2 \cdot 1 \mathrm{ng} . / \mathrm{ml}$. His method includes the addition of ascorbic acid to the medium. However, Ball and Giles (1964), who also added ascorbic acid, found a lower limit of normal of $3.4 \mathrm{ng} . / \mathrm{ml}$. The ratio of the difference in results read at 20 hours with and without added ascorbic acid was $3: 4$. Our lower limit of normal is thus equivalent to $2 \cdot 8 \mathrm{ng}$. $/ \mathrm{ml}$. without ascorbic acid in the standards. This figure is similar to that reported by Davis and Kelly (1962). Our results, therefore, show that the presence of ascorbic acid in standards lowers the final serum folic acid reading but that the effect is not sufficiently pronounced to account for the difference in all normal ranges reported by different workers.

We wish to thank Professor P. B. B. Gatenby for his help and encouragement.

\section{REFERENCES}

Baker, H., Herbert, V., Frank, O., Pasher, I., Hutner, S. H., Wasserman, L. R., and Sobotka, H. (1959). Clin. Chem., 5, 275.

Ball, E. W., and Giles, C. (1964). J. clin. Path., 17, 165.

Davis, R. E., and Kelly, A. (1962). Aust. J. exp. Biol. med. Sci., 40, 437.

Herbert, V. (1961). J. clin. Invest., 40, 81.

-, Baker, H., Frank, O., Pasher, I., Sobotka, H., and Wasserman, L. R. (1960). Blood, 15, 228.

Spray, G. H. (1955). Clin. Sci., 14, 661

, (1964). J. clin. Path., 17, 660.

Toennies, G., Usdin, E., and Phillips, P. M. (1956). J. biol. Chem. 221, 855 .

Waters, A. H., and Mollin, D. L. (1961). J. clin. Path., 14, 335. 